Griya Widya: Journal of Sexual and Reproductive Health, 1(1) 2021, 47-50

Available at: https://journal.nurscienceinstitute.id/index.php/griyawidya

EISSN: 2809-6797

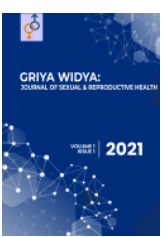

\title{
Hasil Prevalensi Sifilis Reaktif Metode Chlia dalam Donor Darah UDD PMI Lombok Barat
}

\author{
Rina Puspita ${ }^{1 *}$, Yuli Arinta Dewi ${ }^{2}$ \& Laela Kanaya ${ }^{3}$ \\ 1,2,3 Politeknik Bina Trada, Semarang, Indonesia
}

*Email \& Phone: rinapuspita0980@gmail.com; +6282242526668

Submitted: 2021-10-10

DOI: $10.53088 /$ griyawidya.v1i1.253

Accepted: 2021-12-01

Published: 2021-12-29

\begin{tabular}{ll}
\hline \multicolumn{1}{c}{ Keywords: } & Abstract \\
Syphilis & Background: Syphilis is a chronic and systematic disease caused by Treponema \\
Chlia Method & Pallidum. Syphilis transmission through sexual intercourse, can also occur \\
vertivally ftom mother to fetus in the womb or at birt, through blood products \\
and sometimes also transmitted through medical devices. WHO estimates that \\
more than one million people worldwide diagnosed with Sexually Transmitted \\
Diseases every day. \\
Method: The research is a descriptive survey with Cross Sectional design. The \\
data is taken from West Lombok Indonesian Red Cross Blood Donor Unit \\
screening laboratory of period 2020. \\
Result : The data showed the amount of syphilis reactive donors are as many as \\
36 people. The data showed the highest cases among blood dorors are of the \\
age group 40-50 years as many as 12 people or 33,3\% of the total syphilis \\
reactive donors with the most cases only being male as many as 36 people or \\
100\% of the total syphilis reactive blood donors. \\
Implication : Theimplication of this study are: First, prevention efforts against \\
risky sexual behavior so that the incidence of syphilis may decrease. Second, \\
reduce the risk of transmission of sexually transmitted diseases through blood \\
transfusions \\
Novelty: The study was conducted to determine the prevalence of syphilis \\
examination results in blood donors at UDD PMI west Lombok in 2020
\end{tabular}

\section{PENDAHULUAN}

Pelayanan transfusi darah menjadi salah satu upaya kesehatan dalam rangka penyembuhan penyakit dan pemulihan kesehatan. Pelayanan transfusi darah sangat membutuhkan ketersediaan darah atau komponen darah yang cukup, aman, mudah diakses dan terjangkau oleh masyarakat (Kemenkes, 2015). Transfusi darah beresiko menularkan infeksi HIV/AIDS, Hepatitis C, Hepatitis B, Sifilis, Malaria, dan Demam Berdarah Dangue (Sofro, Wati, dan Astuti, 2014). Deteksi infeksi menular lewat transfusi darah dapat 
dilakukan terhadap antigen dan atau antibodi seperti metode rapid test, Enzyme Immuno Assay (EIA), Chemiluminesence Immuno Assay dan tahap materi genetik virus seperti metode Nucleic Acid Test (NAT) (Kemenkes, 2015).

Sifilis merupakan penyakit kronis dan bersifat sistematik yang disebabkan oleh treponema pallidum. Penularan sifilis bisa melalui hubungan seksual, dari ibu ke janin dalam kandungan, saat melahirkan, melalui produk darah, dan kadang juga ditularkan melalui alat kesehatan (Suryani dan Sibero, 2014).

Berdasarkan data dari UDD PMI (Unit Donor Darah Palang Merah Indonesia) Lombok Barat, pada tahun 2018 belum menggunakan metode Chlia untuk pemeriksaan infeksi menular lewat transfusi darah (IMLTD). Pada tahun 2019, UDD PMI Lombok Barat mengeluarkan data hasil pemeriksaan sifilis reaktif sebanyak 51 kasus.

Penelitian terkait Insidensi IMLTD beberapa kali dilakukan di Indonesia (Safro, Wati, dan Astuti, 2014; Achsan, 2014; Akbar, Siregar, \& Amris, 2020;. Azizah \& Prahesti, 2020; Nurminha, 2017; Lestari \& Saputro, 2021; Ena, \& Sunarsih, 2020; Mulia \& Prahesti, 2020). Namun begitu, penelitian yang dilakukan di Lombok Barat pada khususnya, dan di di NTB pada umumnya belum banyak dilakukan. Penelitian ini bertujuan untuk mengetahui hasil pemeriksaan sifilis reaktif pada pendonor darah di UDD PMI Lombok Barat pada tahun 2020.

\section{METODE}

\section{Jenis dan Desain}

Jenis penelitian deskriptif kualitatif dengan rancangan Cross Sectional, dimaksudkan untuk mendapatkan gambaran jumlah pendonor darah dengan Hasil Pemeriksaan Sifilis Reaktif Pada Pendonor Darah di UTD PMI Lombok Barat tahun 2020, yang akan diklasifikasi ke dalam jenis kelamin dan usia pendonornya.

Data dan Sumber Data

Data dalam penelitian ini menggunakan data sekunder yang didapatkan dari data yang sudah dikumpulkan oleh pihak lain UDD PMI Lombok Barat.

Teknik Pengumpulan Data

\section{Persiapan}

Tahapan ini dilakukan survey jumlah pendonor yang diproduksi di UTD PMI Lombok Barat di tahun 2020, kemudian akan dilakukan perijinan untuk melakukan penelitian di UTD PMI Lombok Barat

\section{Pengumpulan Data}

Tahapan ini dilakukan dengan melihat data laporan dari bagian Humas UTD PMI Lombok Barat yang telah dibukukan dan kemudian akan dilakukan pengolahan terhadap data tersebut untuk kemudian dilakukan analisis data.

\section{Analisis Data}

Analisis data dilakukan dengan mendeskripsikan data dan menyajikannya dalam bentuk narasi atau kata-kata yang mengandung makna. 
HASIL DAN PEMBAHASAN

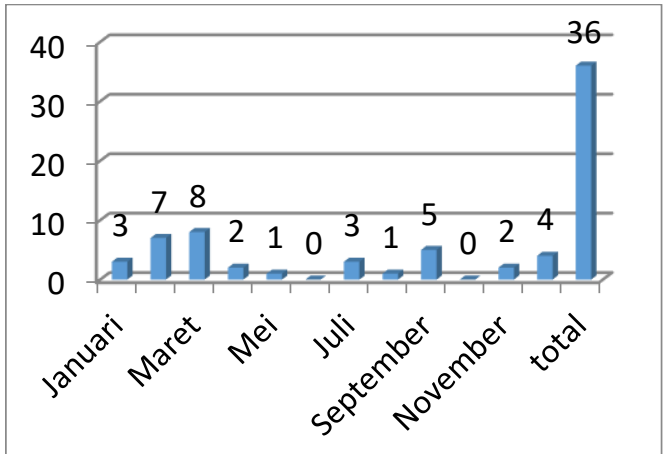

Gambar 1. Hasil Pemeriksaan Sifilis Reaktif Tahun 2020.

Hasil sifilis reaktif di UDD PMI Lombok Barat tahun 2020 terdapat 36 pemdonor darah yang reaktif. Berdasarkan jumlah yang diperoleh dalam penelitian ini paling banyak terdapat pada bulan Maret yaitu sebanyak 8 pendonor darah.

Tabel 1. Data Sifilis Reaktif di UDD PMI Lombok Barat Tahun 2020

\begin{tabular}{lll}
\hline Jenis Kelamin & Jumlah Reaktif Sifilis & Persentase (\%) \\
\hline Laki-laki & 36 & 100,0 \\
\hline
\end{tabular}

Berdasarkan data yang didapatkan hanya ditemukan pada pendonor darah jenis kelamin laki-laki sebnyak 36 atau $100 \%$.

Tabel 2. Data Sifilis Reaktif di UDD PMI Lombok Barat Tahun 2020

\begin{tabular}{cll}
\hline Kelompok Usia & Jumlah Reaktif Sifilis & Persentase (\%) \\
\hline $18-28$ & 8 & 22,2 \\
$29-39$ & 9 & 25,0 \\
$40-50$ & 12 & 33,3 \\
$51-60$ & 6 & 16,7 \\
$<60$ & 1 & 2,8 \\
\hline
\end{tabular}

Berdasarkan data yang didapatkan usia paling banyak menderita sifilis adalah kelompok usia 40-50 tahun sebanyak 12 orang atau 33,3\%.

Hasil ini sejalan dengan penelitian Angka Kejadian Sifilis Padaa Penyumbang Darah di PMI Kota Bandung Periode 2012-2013 mengatakan jumlah penderita laki-laki lebih banyak daripada perempuan dan kelompok usia yang paling banyak menderita sifilis adalah kelompok usia 41-50 tahun (Carnella, 2013).

Penelitian yang dilakukan oleh WHO pada tahun 2012 menunjukkan angka kejadian yang lebih banyak terjadi pada laki-laki daripada perempuan. Hal ini dipengaruhi oleh kehidupan sosial, pergaulan, kebiasaan dan penyimpangan seksual yang lebih banyak terjadi pada laki-laki daripada perempuan. Masih banyaknya masyarakat terutama laki-laki produktif (25-49 tahun) yang tidak menggunakan kondom saat melakukan hubungan seksual, maka akan memperbesar risiko dirinya untuk tertular penyakit kelamin seperti sifilis (Rosa, 2021). 
Berbeda dengan penelitian yang dilakukan oleh Muchlis, jumlah pendonor datah yang reaktif sifilis meningkat dalam periode Januari 2008-Desember 2010, tetapi prevalensi ini mengalami penurunan jumlah angka kejadian sifilis dibandingkan tahun sebelumnya. Perbedaan hasil penelitian ini dengan penelitian sebelumnya dikarenakan metode penelitian yang berbeda.

\section{PENUTUP}

Pada data hasil pemeriksaan sifilis reaktif di UDD PMI Lombok Barat tahun 2020 terdapat 36 sampel darah donor yang dinyatakan reaktif sifilis. Hanya didapatkan pada jenis kelamin laki-laki dan terbanyak pada usia 40-50 tahun.

Diperlukan suatu strategi pelayanan kesehatan yang lebih baik untuk meningkatkan pengendakian dan pencegahan Infeksi Menular Lewat Transfusi Darah (IMLTD) di UDD PMI Lombok Barat.

\section{DAFTAR PUSTAKA}

Achsan, M. (2014). Insidensi Infeksi Menular Lewat Transfusi Darah (IMLTD) di Unit Donor Darah PMI Kota Semarang. Medica Hospitalia: Journal of Clinical Medicine, 2(2).

Akbar, T. I. S., Siregar, S. R., \& Amris, R. N. Gambaran Hasil Skrining Infeksi Menular Lewat Transfusi Darah (IMLTD) Pendonor di Unit Transfusi Darah (UTD) PMI Kabupaten Aceh Utara Periode 2017-2018.

Azizah, S., \& Prahesti, R. (2020). Gambaran Hasil Pemeriksaan Hiv Pada Darah Pendonor di Unit Transfusi Darah (UTD) Palang Merah Indonesia (PMI) Kabupaten Bantul Yogyakarta Tahun 2019 (Doctoral dissertation, Universitas Jenderal Achmad Yani Yogyakarta).

Carnella, R.R.. (2013) Angka kejadian sifilis pada penyumbang darah di pmi kota bandung periode tahun 2012-2013. Available from: http://repository . maranatha.edu/12191/. Diakses tanggal 12 juni 2021.

Ena, A., \& Sunarsih, T. (2020). Gambaran Hasil Uji Saring HIV pada Darah Donor di UTD PMI Kabupaten Gunungkidul Yogyakarta Tahun 2019 (Doctoral dissertation, Universitas Jenderal Achmad Yani Yogyakarta).

Kementrian Kesehatan RI. (2015) Peraturan Menri Kesehatan RI No 91 Tahun 2015 tentang Standar Pelayanan Transfusi Darah

Lestari, C. R., \& Saputro, A. A. (2021). Gambaran Hasil Pemeriksaan HCV, HIV, dan VDRL Pada Pendonor Unit Donor Darah PMI Kabupaten Kudus. IJBSH, 1(1), 11-22.

Mulia, T. O., \& Prahesti, R. (2020). Gambaran Hasil Pemeriksaan Hepatitis B Reaktif pada Darah Pendonor di Unit Transfusi Darah (UTD) PMI Kabupaten Sleman Yogyakarta Tahun 2019 (Doctoral dissertation, Universitas Jenderal Achmad Yani Yogyakarta).

Nurminha, N. (2017). Prevalensi Hasil Uji Saring HbsAg dan Anti HCV pada Darah Donor Di Unit Darah Donor (UDD) RSUD Pringsewu Kabupaten Pringsewu Tahun 2012 2014. Jurnal Analis Kesehatan, 5(1), 527-532.

Rosa L. (2020). Faktor-Faktor Yang Mempengaruhi Terjadinya Penyakit Sifilis Pada Laki-Laki Usia Produktif Di Puskesmas Teladan Medan Periode Januari - September 2019. Tesis. Fakultas Kesehatan Masyarakat Universitas Sumatra-Utara

Safro, M., Wati, D., dan Astuti, R. (2014). Insidensi Penyakit Menular Lewat Transfusi Darah (IMLTD) Di Unit Donor Darah Pmi Kota Semarang. 2 (2) : 88-91

Suryani, D., dan Sibero, H. (2014) Syphilis. J Majority 2014 Vol 3(7) 